\title{
HUBUNGAN ANTARA POLA ASUH ORANG TUA DENGAN PERKEMBANGAN ANAK PADA USIA PRASEKOLAH
}

\section{THE RELATIONSHIP BETWEEN PARENTING STYLE AND CHILDREN'S DEVELOPMENT AGED PRE-SCHOOL}

\author{
Amilia krisdiantini ${ }^{1}$, Bagus Setyoboedi ${ }^{2}$, Ilya Krisnana ${ }^{3}$
}

1. Midwifery Study Programme, Faculty of Medicine, Universitas Airlangga

2. Pediatrics Department, Faculty of Medicine, Universitas Airlangga

3. Maternity and Pediatric Nursing Department, Faculty of Nursing Universitas Airlangga

Alamat koresponden:

Dusun Tengah, Desa Laden RT 02/RW 01 Kab. Pamekasan, Madura

Email : amilia.krisdiantini-2016@,fk.unair.ac.id

\begin{abstract}
ABTRAK
Latar belakang: Perkembangan berkaitan dengan bertambahnya struktur fungsi tubuh yang meliputi kemampuan gerak kasar, gerak halus, dan bahasa serta sosialisasi dan kemandirian. Salah satu faktor yang memperngaruhi perkembangan anak adalah pola asuh yaitu pola interaksi antara orang tua dan anak. Deteksi dini perkembangan perlu dilakukan karena untuk mnegetahui penyimpangan dalam perkembangan. Metode: Metode penelitian ini menggunakan adalah observasional analitik dengan rancangan penelitian cross sectional. Jumlah sampel sebanyak 49 anak dengan teknik pengambilan sampel menggunakan purposive sampling. Variabel Independen adalah pola asuh dan variable dependen perkembangan anak. Intstrumen yang digunakan adalah kuisoner pola asuh dan kuisoner perkembangan anak yaitu KPSP. Teknik analisis data yang digunakan adalah spearman dengan $\alpha=0,05$ dan analisi keeratan kedua hubungan menggunakan correlation coefficient. Hasil: Hasil penelitian menunjukkan bahwa terdapat 33,3\% responden dengan pola asuh permisif memiliki status perkembangan sesuai atau normal dengan usianya, orang tua dengan pola asuh demokratis juga terdapat 53,7\% responden yang perkembangannya sesuai atau normal dengan usianya, sedangkan pola asuh otoriter terdapat $40,0 \%$ responden yang sesuai atau normal dengan usainya. Hasil uji spearmen diketahui masing-masing pola asuh, yaitu pola asuh permisif dengan $p$ value 0,928 , pola asuh demokratis dengan $p$ value 0,023 , dan pola asuh otoriter dengan $p$ value 0,420 . Kesimpulan: data tersebut menunjukkan bahwa ada hubungan pola asuh orang tua dengan perkembangan yaitu pola asuh demokratis.
\end{abstract}

Kata kunci : perkembangan anak, pola asuh orang tua, balita

\begin{abstract}
Background: Development is related to the increase in the structure of bodily functions which Include tge ability of gross and fine motor skill, languange, and socializationand independence. One of the factors that influence a child's development is parenting, which is the pattern of interaction between parents and children. Early detection of development needs to be done in order to know deviations in development. Method: This research method used an observational analytic cross-sectional study design. The number of samples was 69 toddlers with a sampling technique using purposive sampling. The independent variable is parenting and the dependent variable is child development. The instruments used were parenting questionnaire and child development questionnaire, namely KPSP. Data analysis technique used was the spearman with $\alpha=0.05$ and the analysis of the closeness of the two relationships using correlation coefficient. Results: The results showed that there were $33.3 \%$ of respondents with permissive parenting had developmental status in accordance with or normal with their age, parents with democratic parenting also had $53.7 \%$ of respondents whose development was in accordance with or normal with their age, while
\end{abstract}


authoritarian parenting there are $40.0 \%$ of respondents who are appropriate or normal for their age. Spearmen test results are known for each parenting, namely permissive parenting with $p$ value 0.928 , democratic parenting with $p$ value 0.023 , and authoritarian parenting with $p$ value 0.420 . Conclusion: the data shows that there is a relationship between parenting and developmental patterns, those are democratic parenting and permissive parenting.

Keywords: child development, parenting, toddlers birth length ( $p=<0.001, R R=0.256)$, and the baby's birth weight ( $p=<0.001, R R=0.208)$ with stunting. Multivariateanalysis showed maternal height and ANC visit as the significant risk factors of stunting. Conclusion: Maternal height and the frequency of ANC visits were the risk factors for stunting among toddlers aged 24-59 months in Tambak Wedi Public Health Center in Surabaya.

Keywords: stunting, toddlers risk factors

\section{PENDAHULUAN}

Perkembangan berkaitan dengan bertambahnya struktur fungsi tubuh yang meliputi kemampuan gerak kasar, gerak halus, bicara, dan bahasa serta sosialisasi dan kemandirian (Soetjiningsih dan Ranuh, 2015). Pembinaan tumbuh kembang anak secara komprehensif dan berkualitas diselenggarakan melalui kegiatan stimulasi, deteksi dan intervensi dini. Stimulasi yang memadai artinya rangsangan otak balita sehingga perkembangan kemampuan gerak, bicara dan bahasa, sosialisasi dan kemandirian pada balita berlangsung secara optimal sesuai dengan umur anak. Stimulasi adalah kegiatan merangsang kemampuan dasar anak umur 0-6 tahun agar anak tumbuh dan berkembang secara optimal (Kemenkes RI, 2012). Berdasarkan stimulasi, deteksi dan intervensi dini tumbuh kembang anak, perkembangan anak dapat dinilai melalui skrining KPSP (Kuesioner Pra Skrining Perkembangan). Dari hasil skrining tersebut dapat diketahui anak anak yang mengalami keterlambatan perkembangan sejak usia dini. Anak usia 4-6 tahun yang mengalami keterlambatan perkembangan dikatakan sebagai suatu kondisi yang harus segera di tangani. Kemampuan berbahasa merupakan indikator seluruh perkembangan anak. Kurangnya stimulasi akan dapat menyebabkan gangguan bicara dan berbahasa bahkan gangguan ini dapat menetap (Kemenkes RI, 2013)

Menurut riskesdas (2018), perbandingan indeks perkembangan anak pada usia 659 bulan sebanyak 88,3\% yang terdiri dari Literasi (64,6\%), Fisik (97,8\%), Sosial emosional (69,9\%), Learning (95,2\%). Pada tahun 2010 gangguan pertumbuhan dan perkembangan pada anak di Indonesia mencapai 35,7\% dan tergolong dalam masalah kesehatan masyarakat yang tinggi menurut acuan WHO karena masih diatas $30 \%$ (Riskesdas, 2010). Ikatan Dokter Anak Indonesia (IDAI) Jawa Timur pada tahun 2014 melakukan pemeriksaan terhadap 2.634 anak dari usia 0-72 bulan. Pemeriksaan deteksi tumbuh kembang di Jawa Timur tahun 2009 sebesar 64,03\% dan masih di bawah target 
$80 \%$, pada tahun 2010 telah dilakukan pada 2.321 .542 anak balita dan prasekolah atau 63,48\% dari 3.657.353 anak balita. Cakupan tersebut naik dibandingkan tahun 2009, dan pada tahun 2011 cakupan naik menjadi 69\% dan masih di bawah target 80\% (Dinkes Jatim, 2011). Studi terdahulu yang dilakukan oleh Era nurisa, dkk (2017) mendapatkan hasil penelitian yang menunjukkan terdapat hubungan antara pola asuh orang tua dengan perkembangan anak usia prasekolah. Sri Yuniarti (2017), mengatakan bahwa ada hubungan antara pola asuh orang tua dengan perkembangan anak. Menurut Israfil (2015) menyatakan bahwa ada hubungan antara pola asuh dengan perkembangan anak usia prasekolah.

Studi pendahuluan yang dilakukan pada bulan September 2019 oleh peneliti di TK Nahdlatus Subban Pamekasan-Madura ditemukan adanya 1-2 anak dari 108 anak mengalami penyimpangan di perkembangan serta belum pernah dilakukannya skrining deteksi dini penyimpangan terhadap perkembangan. Tujuan dari penelitian ini untuk menganilisis Hubungan Antara Pola Asuh Orang Tua Dengan Perkembangan Anak usia prasekolah Di TK Nahdlatus Subban Pamekasan-Madura. Hipotesis penelitian "Ada Hubungan Antara Pola Asuh Orang Tua dengan Perkembangan Anak Usia Prasekolah di TK Nahdlatus Subban Pamekasan-Madura"

\section{METODE}

Jenis penelitian yang digunakan adalah observasional analitik dengan rancangan bangun penelitiancross sectional.Populasi dalam penelitian ini seluruh balita yang bersekolah di TK Nahdlatus Subban Pamekasan, Madura dengan jumlah 108 murid. Teknik pengambilan sampel menggunakan metode purposive sampling. Pada pelaksanaan penelitian, responden yang didapatkan sebanyak 49 responden. Analisis data pana penelitian ini menggunakan spearman dengan $\alpha=0,05$ dan analisis keeratan kedua hubungan menggunakan correlation coefficient

Variabel Independen adalah pola asuh dan variable dependen perkembangan anak. Instrumen yang digunakan adalah kuisoner pola asuh dan kuisoner perkembangan anak yaitu KPSP. Kriteria hasil ukur pada kuisioner pola asuh Pada akhir setiap tipe pola asuh, skor di jumlah. Total jumlah yang tertinggi mengidentifikasikan pola asuh tersebut dengan skala rasio. Pada perkembangan Anak kriteria hasil ukur Terdapat dua tipe penilaian Kode 1 Sesuai : jika nilai kuesioner 9 dan 10 Kode 2 Tidak Sesuai : jika nilai 
kuesiner dibawah angka 9 dan 10 yaitu meragukan dan menyimpang dengan skala nominal

Pengumpulan data dilakukan pada bulan april-mei 2020 dimulai dengan mengurus perijinan untuk pengumpulan data, menghubungin kepala sekola TK Nahdlatus Subban Pamekasan-Madura untuk meminta izin penelitian, meminta bantuan kepada kepala sekolah TK Nahdlatus Subban Pamekasan-Madura untuk mengumpulkan orang tua siswa yang bersekolah di TK tersebut, menjelaskan kepada responden tujuan dari penelitian ini dan menjelaskan cara mengisi kuisioner dan meminta persetujuan untuk bersedia menjadi responden, dan melakukan pengumpulan data dengan cara membagikan kuisioner pola asuh dan perkembangan anak (KPSP).

\section{HASIL DAN PEMBAHASAN}

\section{Hubungan Antara Pola Asuh Orang Tua dengan Perkembangan Anak}

Tabel 1 Hubungan Pola Asuh Orang Tua dengan Perkembangan Anak pada Usia prasekolah di TK Nahdlatus Subban Pamekasan-Madura

\begin{tabular}{ccccccccc}
\hline & & \multicolumn{7}{c}{ Perkembangan Anak } \\
\hline Pola asuh & \multicolumn{2}{c}{ Sesuai } & Tidak sesuai & Jumlah & P value & $\begin{array}{c}\text { Correlation } \\
\text { coefficient }\end{array}$ \\
\hline & $\mathrm{N}$ & $\%$ & $\mathrm{~N}$ & $\%$ & $\mathrm{~N}$ & $\%$ & & \\
\hline Permisif & 1 & $33,3 \%$ & 2 & $66,7 \%$ & 3 & $100 \%$ & 0,928 & $-0,013$ \\
Demokratis & 22 & $53,7 \%$ & 19 & $46,3 \%$ & 41 & $100 \%$ & 0,023 & 0,324 \\
Otoriter & 2 & $40,0 \%$ & 3 & $60,0 \%$ & 5 & $100 \%$ & 0,420 & 0,118 \\
\hline Total & 25 & & 24 & & 49 & $100 \%$ & & \\
\hline
\end{tabular}

Berdasakan tabel 1 terdapat tiga pola asuh yang diteliti yaitu pola asuh

permisif, demokratis, dan otoriter pada tiga pola asuh tersebut dilakukan uji pada perkembangan anak dengan hasil $p$ value pola asuh permisif $0,928, p$ value pola asuh demokratis 0,023 , dan $p$ value pola asuh otoriter 0,420 .

\section{Hubungan Antara Karakteristik Responden dengan Perkembangan Anak}

Tabel 2 Hubungan antara Karakteristik Responden dengan Perkembangan Anak pada Usia prasekolah di TK Nahdlatus Subban Pamekasan-Madura

\begin{tabular}{cccccc}
\hline & & \multicolumn{3}{c}{ Perkembangan anak } \\
\hline Karakteristik & $\mathrm{N}$ & $\%$ & $P$ value & $\begin{array}{c}\text { Correlation } \\
\text { coefficient }\end{array}$ & Keterangan \\
\hline Usia Anak & 49 & $100 \%$ & 0,003 & $-0,421$ & $\begin{array}{c}\text { Ada Hubungan } \\
\text { Tidak Ada Hubungan } \\
\text { Jenis Kelamin }\end{array}$ \\
$\begin{array}{c}\text { Pendidikan } \\
\text { Terakhir }\end{array}$ & 49 & $100 \%$ & 0,494 & 0,100 & Tidak Ada Hubungan \\
Pekerjaan & 49 & $100 \%$ & 0,708 & $-0,055$ & Tidak Ada Hubungan \\
\hline
\end{tabular}

Berdasarkan tabel 2 menunjukkan bahwa tidak ada hubungan antara karakteristik responden dengan perkembangan anak. Uji ini menggunakan uji spearman yang 
menunjukkan bahwa nilai dari karakteristik responden yaitu usia anak dengan $p$ value 0,003 yang berarti terdapat hubungan dengan perkembangan anak.

\section{Hubungan Antara Lama Interaksi Orang Tua dan Jam Sekolah Anak dengan Perkembangan}

Tabel 3 Hubungan antara Lama Interaksi dan Jam Sekolah dengan Perkembangan Anak pada Usia prasekolah di TK Nahdlatus Subban Pamekasan-Madura

\begin{tabular}{cccccc}
\hline & \multicolumn{5}{c}{ Perkembangan anak } \\
\hline Karakteristik & $\mathrm{N}$ & $\%$ & $\begin{array}{c}P \\
\text { value }\end{array}$ & KK & Keterangan \\
\hline Lama Interaksi & 49 & $100 \%$ & 0,785 & $-0,040$ & Tidak Ada Hubungan \\
Jam Sekolah & 49 & $100 \%$ & 0,251 & 0,167 & Tidak Ada Hubungan
\end{tabular}

Berdasarkan tabel 5.4 setelah dilakukan uji sprearman menunjukkan bahwa nilai $p$ value $>0,05$ yang berarti tidak terdapat hubungan dengan perkembangan anak.

Hasil uji statistik non parametrik Spearman ini merupakan uji alternatif ketika tidak memenuhi asumsi atau prasyarat korelasi pearson. Korelasi spearman-rho menganalisis hubungan variabel dari dua subjek yang berbeda atau dalam hal ini dua variabel yang berbeda berdasarkan peringkat dan bukan nilai asli dari data variabel. Oleh karena itu, sekalipun ketika menganalisis data menggunakan korelasi spearman-rho dengan memasukkan data variabel berskala interval atau rasio maka dasar penghitungan koefisien korelasi dilakukan hanya berdasarkan peringkat nilai tersebut dari urutan keseluruhan nilai. Korelasi ini termasuk kelompok statistik non parametrik dan direkomendasikan digunakan jika sampel $>30$ dan tied ranks (nilai dengan peringkat yang sama) relatif sedikit, didapatkan nilai $p$ value dari masing masing pola asuh, yaitu pola asuh permisif dengan nilai $\mathrm{p}=0,928$, pola asuh demokratis dengan nilai $\mathrm{p}=0,023$, dan pola asuh otoriter dengan nilai $\mathrm{p}=0,420$ artinya hanya ada satu tipe pola asuh yang memiliki hubungan dengan perkembangan anak di TK Nahdlatus Subban PamekasanMadura. Nilai koefisien dari pola asuh demokratis 0,324 menunjukkan adanya arah hubungan yang positif dengan kekuatan rendah.

Hasil penelitian ini sesuai dengan penelitian yang dilakukan oleh Era Nurisa, dkk (2017) mendapatkan hasil penelitian yang menunjukkan terdapat hubungan antara pola asuh orang tua dengan perkembangan anak usia prasekolah. Zuraida, dkk (2018) mendapatkan hasil penelitian yang menunjukkan terdapat hubungan antara pola asuh orang tua dengan keterlambatan bicara pada anak usia 3-5 tahun dengan $(p=0,025<\alpha$ $=0,05)$. Putri Atika (2018), mengatakan bahwa terdapat hubungan antara pola asuh orang 
tua dengan perkembanan anak dengan $(p=0,01<0,05)$. Sri Yuniarti $(2017)$, mengatakan bahwa ada hubungan antara pola asuh orang tua dengan perkembangan anak (didapatkan $p$ value $0,013<\alpha 0,05)$.

Tidak semua orang tua yang menerapkan pola asuh demokratis memiliki anak perkembangan sesuai/normal, karena dari hasil penelitian ini menunjukkan 19 responden $(54,5 \%)$ mengalami penyimpangan perkembangan anak. Dilihat dari angka diatas, bahwa orang tua yang menggunakan pola asuh demokratis juga dapat mengalami perkembangan yang menyimpang.

Pola asuh orang tua dalam perkembangan anak sangat membantu anak dalam mencapai dan melewati pertumbuhan dan perkembangan sesuai tingkatan usianya dengan normal (Supartini, 2012). Perlakuan orang tua pada anak akan mempengaruhi sikap anak dan perilakunya. Dalam mengasuh anak orang tua cenderung menggunakan pola asuh tertentu. Kemampuan personal sosial ini akan dipengaruhi pola asuh yang diterapkan orang tua pada anak, apabila pola asuh yang diterapkan baik maka kemampuan personal sosial anak akan bersifat positif (Hurlock, 2012).

Pengasuhan keluarga selama lima tahun pertama kehidupan sangat berpengaruh terhadap 4 domain perkembangan yaitu motorik, kognitif, bahasa, dan sosialemosional anak. Orang tua harus selalu memberi rangsang atau stimulasi kepada anak dalam semua aspek perkembangan baik motorik kasar maupun halus, bahasa dan personal sosial. Sehingga perkembangan anak berjalan optimal, kurangnya stimulasi dapat menyebabkan keterlambatan perkembangan anak. Anak dapat dikatakan mengalami keterlambatan perkembangan secara menyeluruh ketika anak mengalami keterlambatan pada lebih dari dua domain perkembangan (Soetjiningsih, 2012)

Faktor yang mempengaruhi perkembangan anak ada dua yaitu faktor internal dan eksternal. Pada faktor intenal terdapat ras/etnik atau bangsa, umur, jenis kelamin, genetik, dan keluarga, dan pada faktor eksternal terdapat 3 faktor yaitu faktor prenatal, faktor persalinan, faktor pasca persalinan. Pada penelitian ini menunjukkan bahwa, jenis kelamin, pendidikan terkahi orang tua, pekerjaan orang tua, lama interaksi, jam sekolah tidak terdapat hubungan dengan perkembangan anak dikarenakan telah dilakukan uji oleh peneliti terdapat pada Tabel 2 dan Tabel 3 bahwa usia anak memiliki hubungan dengan perkembangan anak dengan nilai $\mathrm{p}=0,003$ yang menunjukkan bahwa selain keluarga, usai anak juga dapat berpengaruh dalam perkembangan anak. Hasil ini sesuai dengan 
teori didalam buku SDIDTK (2016) yang menyatakan usia berada dalam salah satu faktor yang mempengaruhi perkembangan anak yaitu di faktor internal. Jam sekolah yang diterapkan di TK Nahdlatus Subban Pamekasan-Madura terbagi menjadi 2 yaitu untuk kelas PAUD ditetapkan 1 jam dari jam 8-9 pagi dan untuk kelas TK A dan TK B ditetapkan menjadi 2 jam yaitu dari jam 8-10 pagi. Peran sebagai seorang bidan dapat juga menjadi salah satu hal yang mendukung untuk deteksi dini terhadap perkembangan anak yang bisa dilakukan dengan cara penyuluhan kepada orang tua yang memiliki balita, dan melakukan pemeriksaan rutin di puskesmas atau di poyandu setempat.

\section{KESIMPULAN DAN SARAN}

Dapat disimpulkan bahwa Ada hubungan pola asuh orang tua dengan perkembangan anak yaitu pola asuh deomkratis di TK Nahdlatus Subban, PamekasanMadura. Penelitian ini disarankan kepada orang tua dan masyarakat Untuk hasil perkembangan anak yang optimal disarankan untuk menggunakan semua pola asuh tidak hanya berpedoman pada satu pola asuh saja, belajar tentang cara pengasuhan yang dapat mengembangkan anak sesuai usianya.

\section{DAFTAR PUSTAKA}

Ana Nurul I. T. (2011). Pengaruh Pola Asuh Orang Tua Dan Self-Regulated Learning Terhadap Prokrastinasi Pada Siswa Mts N 3 Universitas Islam Negeri ( Uin .Skripsi. Universitas Negeri Islam Syarif Hidayatullah Jakarta.

Anggraini, W. (2011). Keterlambatan Bicara (Speech Delay) Pada Anak ( Studi Kasus Anak Usia 5 Tahun). Skripsi. Universitas Negeri Semarang

Asnaniar WOS, Lasini MB (2016). Hubungan Lingkar Kepala Dengan Perkembangan Motorik Anak Usia 1-24 Bulan di Rumah Sakit Ibu dan Anak Pertiwi Makassar. Jurnal Ilmiah Kesehatan Diagnosis.

Atika Putri, D.W. (2018). Hubungan Pola Asuh Orang Tua Dan Perkembangan Balita Di Poyandu Flamboyan Kelurahan Rungkut Mananggal Surabaya. Skripsi. Universitas Airlangga Surabaya

Candrasari, J.P. (2014). Hubungan Pola Asuh Orang Tua Dengan Perkembangan Bahasa Anak Prasekolah di RA Semai Benih Bangsa Al-Fikri Manca Bantul Yogyakarta. Naskah publikasi. Sekolah tinggi kesehatan 'aisyiyah yogyakarta

Departemen kesehatan RI. (2018). Pelayanan Stimulasi Deteksi Intervensi Dii Tumbuh Kembang Anak. Kementrian kesehatan republik indonesia

Diana, M.F. (2010).jurnal kesehatan masyarakat : Pemantauan perkembangan anak balita. Vol. 4(2)

Elizabeth B. Hurlock, Developmental Psychology, Terj. Istiwidayanti dan Soedjarwo, Psikologi Perkembangan Sepanjang Rentang Kehidupan (Jakarta: Erlangga, 1980), h. 3 
Hurlock, E.B. (2012). Psikologi Perkembangan. Edisi ke-5. Jakarta : Erlangga

Kementerian Kesehatan RI. (2016). Pedoman Pelaksanaan Stimulasi, Deteksi

Dan Intervensi Dini Tumbuh Kembang Anak Ditingkat Pelayanan Kesehatan Dasar tandar. Jakarta : Departemen Kesehatan RI, hlm. 3-20.

Martani, W. (2012). Jurnak psikologi : metode stimulasi dan perkembangan emosi anak usian dini, vol.39 (1), pp 112-120

Medise, B.E. (2013). Mengenal keterlambatan perkembangan umum pada anak. (online). Idai.or.id. diperoleh dari : https://www.idai.or.id/artikel/seputar-kesehatananak/mengenal-keterlambatan-perkembangan-umum-pada-anak (september 2019)

Moersintowati, N. B.(2010). Tumbuh Kembang Anak Dan Remaja. In Nancy Pardede. Masa Remaja. Jakarta: CV Sagung Seto.

Mulqiah, Z., Santi, E., \& Lestari, D. R. (2017). Pola Asuh Orang Tua Dengan Perkembangan Bahasa Anak Prasekolah (Usia 3-6 Tahun).Dunia Keperawatan, 5(1), 61.

Nurmalasari, A. (2016). Hubungan Intesitas Penggunaan Gadget DenganKeterlambatan Perkembangan Pada Aspek Bicara Dan Bahasa Pada Balita Di Kelurahan Tambakrejo Surabaya. Skripsi. Universitas Airlangga Surabaya

Rachmawati, Y. L. (2015). Pos Deteksi Dini Tumbuh Kembang Komprehensif Di Kecamatan Jabung, Kabupaten Malan,. 1(1), pp 2477-2356

Rohmah, M., Astikasari, N. D., \& Weto, I. (2018). Analisis Pola Asuh Orang Tua Dengan Keterlambatan Bicara Pada Anak Usia 3-5 Tahun Analysis Of Parenting Patterns With Speech Delay In Children Aged 3-5 Years Bahasa Dan Bicara Pada Anak Usia 2 Berdasarkan National Center For. V(1), 32-42.

Sanitasari, D.R.(2017). Jurnal rekursif : Sistem Motoring Tumbuh Kembang Anak Usia 0-5 Tahun Berbasis Android, vol. 5 (1), pp 2303-0755

Setyowati, E. (2010). Hubungan Antara Pengetahuan, Sikap, Perilaku Ibu DenganPerkembangan Bahasa Anak Usia 24-36 Bulan Di Kelurahan

Krembangan Selatan Surabaya. Tesis. Universitas Airlangga Surabaya

Soetjiningsih, (2012). Tumbuh Kembang Anak. Laboratorium Ilmu Kesehatan Anak. Surabaya: Universitas Airlangga

Sriyanti lilik. (2014). Psikologi Anak. (online). Salatiga: STAIN Salatiga Press, http:/erepository.perpus.iainsalatiga.ac.id/2198/2/Psikologi\%20Anak\%20pdf.pdf

Suherlina, yulia. (2011). Manfaat Deteksi Dini Tumbuh Kembang Anak. (online). Kemendikbud.go.id.

diperoleh

dari

http://repositori.kemdikbud.go.id/506/1/03\%20DETEKSI\%20DINI.pdf (september 2019)

Tjandrajani A. (2012). Keluhan Utama pada Keterlambatan Perkembangan

Umum di Klinik Khusus Tumbuh Kembang RSAB Harapan Kita. Sari

Pediatri.

Windari. E. N, Trisintyandik. I, Santoso. D. (2017).Hubungan Pola Asuh Orang

Tua Dengan Perkembangan Anak Prasekolah Pada Ibu Yang Menikah Dini Di Wilayah Puskesmas Jabung. Artikel Hasil Penelitian. Universitas brawijaya malang

Windra, A. (2020) . Hubungan Pola Asuh Orang Tua Dengan Pertumbuhan dan Perkembangan Anak Prasekolah: jurnal kesehatan poltekes ternate .(online)13 (1), pp 46-52diperoleh dari https://www.researchgate.net/publication/342707415_Hubungan_Pola_Asuh_Oran g_Tua_Dengan_Pertumbuhan_Dan_Perkembangan_Anak_Prasekolah (11 agustus 2020) 
Yuniarti. S, Andriyani. M. (2017). Hubungan Pola Asuh Orang Tua Dengan Perkembangan Anak Prasekolah Di R.A Almardiyah Rajamandala Bulan Juli 2016 : Prosiding Seminar Nasional Ilmu Pengetahuan dan Teknologi Jenderal Achmad Yani (SNIJA) 2017, (online). Diperoleh dari http://lppm.unjani.ac.id/wp-content/uploads/2018/10/103-111-Sri-YuniartiSTIKES-A-Yani.pdf (28 agustus 2020). 